\title{
PECULIARITIES OF AEROBIC DEVELOPMENT IN KAYAK ROWERS PREPARING FOR 1000 M EVENT
}

\author{
Ričardas Nekriošius ${ }^{1}$, Rūta Dadelienė ${ }^{2}$, Egidijus Balčiūnas ${ }^{2}$, Kazys Milašius ${ }^{2}$ \\ Lithuanian Sports University ${ }^{l}$, Kaunas, Lithuania \\ Lithuanian University of Educational Sciences ${ }^{2}$, Vilnius, Lithuania
}

\begin{abstract}
Research background and hypothesis. Lithuanian scientific publications mostly deal with kayak rowers' preparation for 200 and $500 \mathrm{~m}$ events, while $1000 \mathrm{~m}$ event is hardly analyzed yet.

Research aim was to project scientifically based program of kayak rowers' preparation for $1000 \mathrm{~m}$ event, which is to develop aerobic capacity in different mezo-cycles, and to evaluate its efficiency.

Research methods. Preparation of kayak doubles crew members was investigated; the athletes were the $5^{\text {th }}$ place winners of 2013 World Cup II event. The carried out training load for aerobic capacity development was divided into 5 zones of intensity. During training sessions, computer program Garmin Connect measured the distance and speed of a boat, as well as athletes' heart rate (HR). Athletes' aerobic capacity at critical intensity level (CIL) and anaerobic threshold (ANT) was established using gas analyser 'Oxycon Mobile'.

Research results. As the research showed, the kayak rowers in mezzo-cycles of both preparatory and competition periods carried out very little training load in the fifth zone of intensity. Considerable is also the fact that during competition period, in mezzo-cycle, the total number of kilometres decreased from 218 to $158 \mathrm{~km}$.

Discussion and conclusions. The research demonstrated that training workloads in the first and the second zones for elite kayak rowers preparing for $1000 \mathrm{~m}$ event in the first mezzo-cycle of competitive period were diminished comparing to the workload carried out in the preparatory period, while the amount of workload in the fourth zone was considerably increased. Adaptation of the two elite athletes to applied training loads is different, although they were following the same program. Due to this fact, the training process of those athletes is recommended to be given more individual approach, though they are rowing one boat.
\end{abstract}

Keywords: kayak rowing, preparatory and competitive periods, training mezzo-cycles, aerobic capacity.

\section{INTRODUCTION}

$\mathrm{T}$ The stage of contemporary kayak rowing training evolution bears characteristic feature of active search for and introduction of still more effective means and methods, which are to increase the efficiency of pedagogical impact. As a matter of fact, constant progress in sport results may only occur alongside stable increase in body functional systems capacity and physical working capacity; the latter can be attained in the process of planning and carrying-out preparation of kayak rowers (Skernevičius et al., 2003). Kayak rowing sport is classified as event requiring mixed anaerobic alactic energy production, as well as great aerobic capacity and endurance; such reactions of energy production prevail in $1000 \mathrm{~m}$ event when athletes overcome it in 3.00 up to $4.00 \mathrm{~min}$ and make $81.8 \%$ of energy production (Astrand, 2001). Slow twitch, enduring muscle fibres with their inner intense aerobic processes are active participants in muscle work (Wilmore et al., 2008). In $1000 \mathrm{~m}$ event, good sport results are being achieved by athletes possessing relative maximal oxygen uptake 
$70 \mathrm{ml} / \mathrm{min} / \mathrm{kg}$ (Kahl, 1998); due to this fact the significance and time allocation to aerobic capacity development for kayak rowers preparing for this event becomes obvious.

Lithuanian scientific publications mostly deal with kayak rowers' preparation for $200 \mathrm{~m}$ and $500 \mathrm{~m}$ events (Rudzinskas et al., 1997, 2000, 2001; Skernevičius et al., 1998, 2002, 2003, 2004; Balčiūnas, 2009, 2010), as in those events achievements of Lithuanian kayak rowers in international competitions are rather distinguished; however, preparation of Lithuanian kayak rowers for $1000 \mathrm{~m}$ event is hardly investigated and sports achievements of the athletes are not so much significant.

It becomes relevant to perform deeper scientific investigations on theoretical basis of Lithuanian elite kayak rowers' preparation, as well as content and methods of this preparation in developing aerobic capacity, altogether providing accuracy on the efficiency of the methods. Scientific problem appears on projecting a scientifically based kayak rowers' preparation for $1000 \mathrm{~m}$ event program and testing its efficiency.

The aim of the work was to project scientifically based program for kayak rowers' preparation for $1000 \mathrm{~m}$ event, which would develop aerobic capacity in different mezzo-cycles, and to provide evaluation of its efficiency.

\section{RESEARCH METHODS}

The research was carried out in the first year of four-year Olympic cycle, during the last mezzocycle of the preparatory period, as well as in the first mezzo-cycle of the competitive period, respectively in 2013 February 26-March 17, and April 22-May 16.

The investigation dealt with kayak doubles crew members' preparation; the athletes were the $5^{\text {th }}$ place winners in 2013 World Cup II event competitions, thus attaining the best $1000 \mathrm{~m}$ event Lithuanian kayak rowing result ever. The carried out training load for aerobic development was brought into 5 zones of intensity:

- first zone - working intensity under aerobic threshold (AT), HR - $140 \pm 10 \mathrm{~b} / \mathrm{pm}$, blood lactate concentration - up to $2 \mathrm{mmol} / \mathrm{l}$;

- second zone - working intensity - HR $155 \pm 5 \mathrm{~b} / \mathrm{pm}$, blood lactate concentration 2.1-3 mmol/1;

- third zone - working intensity - HR $-165 \pm$ $5 \mathrm{~b} / \mathrm{pm}$, blood lactate concentration $-3.1-$ $5 \mathrm{mmol} / \mathrm{l}$;

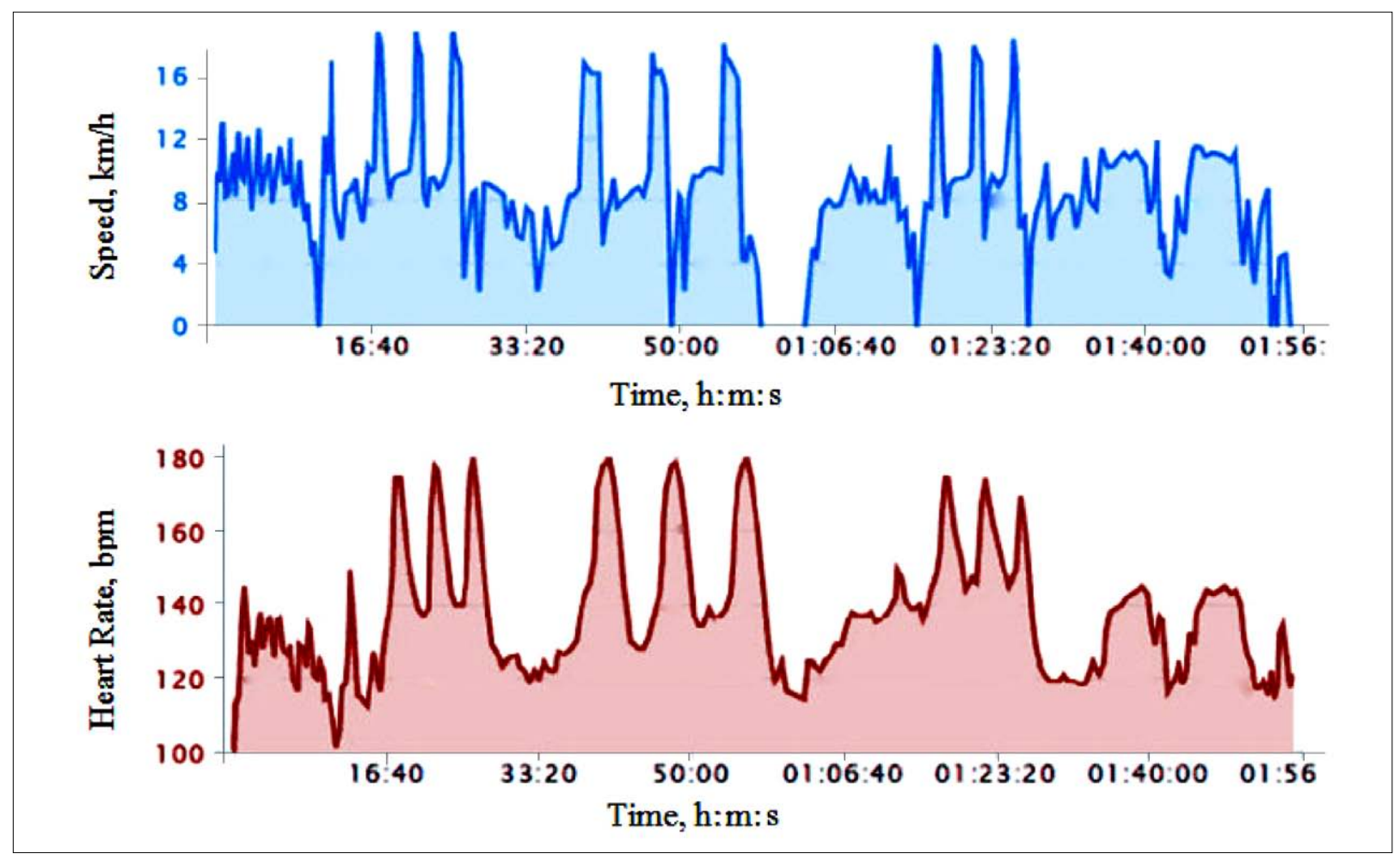

Figure. Distance, overcome by kayak rower R. N., and the change of boat pace and pulse rate in one training session 
- fourth zone - working intensity - HR $175 \pm 5 \mathrm{~b} / \mathrm{pm}$, blood lactate concentration $5.1-8 \mathrm{mmol} / \mathrm{l}$

- fifth zone - working intensity - HR - 180$185 \mathrm{~b} / \mathrm{pm}$, blood lactate concentration $8.1 \mathrm{mmol} / 1$ and higher.

During the training sessions, computer program Garmin Connect, Forerunner 910 XT was employed to measure the distance and speed of a boat, as well as the athletes' pulse rate (PR) (Figure). Capillary blood sample used to be taken, establishing $\mathrm{La}$ concentration. In each of the practices, in micro-cycle and mezzo-cycle, time for training load carried out in different intensity zones, and distance $(\mathrm{km})$ used to be measured. Gas analyser 'Oxycon Mobile' was used to set out the indices of lung ventilation (LV), heart rate (HR), maximal oxygen uptake $\left(\mathrm{VO}_{2} \mathrm{max}\right)$, oxygen pulse $(\mathrm{OP})$, working capacity (W), working efficiency at the limits of critical intensity (CIL) and anaerobic threshold (ANT). After the experienced load at CIL, blood lactate concentration used to be measured. The protocol of aerobic capacity indices had been compiled following the reference of J. Skernevičius et al. (2004).

Our elaborated training program underwent discussion by athletes, coaches and scientists; it hardly experienced any changes within the process of athletes' preparation.

\section{RESEARCH RESULTS}

The first mezzo-cycle of competitive period for our investigated kayak rowers possessed four micro-cycles. The first micro-cycle was aimed at supercompensation, during which athletes' physical and functional body condition investigations were performed. In this microcycle, water rowing consisted of $33.8 \mathrm{~km} ; 43.2 \%$ of them were performed at the first zone intensity, and the fourth zone of intensity embraced the least amount of the training load - only $10.2 \%$ (Table 1). In the second micro-cycle - the one of great aerobic and glycolytic training load, workload was considerably less in the second zone, but the increase happened in the third zone - up to $23.5 \%$ from total workload; training workload also used to be carried out in the fourth and fifth zones and reached $10.8 \%$. The third micro-cycle of special workload was specific in its decreased workload in the first and the second zones, and increased in the third zone - up to $33.3 \%$, while in the fourth zone it was up to $23.7 \%$. The fourth competitive micro-cycle included participation in the second World Cup event, with three rowing in preliminary rounds, semi-finals and finals, winning the fifth place and reaching the best time ever in Lithuanian kayak double $-3 \min 12.63 \mathrm{~s}$. In this micro-cycle, only $19.2 \mathrm{~km}$ were rowed, the greatest workload carried out in the first zone - which made $39.2 \%$ of total work; a lot of work was performed in the third zone $-26.6 \%$, and $19.4 \%$ was allocated to the work in the fourth zone.

Comparison of the on-water rowing work amount in this mezzo-cycle with the special onwater rowing mezzo-cycle in preparatory period (Table 1) shows the change of work intensity in competitive mezzo-cycle with decreased per cent of workload amount in the first and the second zones, as well as an increase of it in the third and the fourth zones - respectively up to 26.2 and $16.1 \%$. The research showed rather little workload, carried out by the kayak rowers in the fifth zone of intensity both in preparatory and competitive mezzo-cycles. It should be noted that the total amount of rowed kilometres in competitive period was considerably less - it decreased from $218.7 \mathrm{~km}$ in preparatory period mezzo-cycle to $158.1 \mathrm{~km}$.

Research on aerobic capacity, performed using gas analyser prior to special mezzo-cycle in preparatory period (testing I) and after it (testing II), as well as after the competitive mezzo-cycle in competitive period (testing III), in two days after participation in the World Cup events showed that the majority of aerobic capacity indices of both athletes used to considerably increase during the preparatory period memo-cycle, although changes difficult to explain had occurred (Table 2). Lung ventilation for the athlete R. N. at critical intensity level had increased by $10 \mathrm{l} / \mathrm{min}$, and for A. O. it had decreased by $21 \mathrm{l} / \mathrm{min}$. Very similar change of this index was observed also at anaerobic threshold limit. Pulse rate for both athletes at CIL used to increase significantly. Very great oxygen pulse changes were observed for the investigated R. N. (from 26.3 to $31.9 \mathrm{ml} / \mathrm{b}$ ), for A. O. these changes were less. Working capacity for both of the athletes used to increase respectively by $40 \mathrm{~W}$ and $60 \mathrm{~W}$, work efficiency index used to decrease insignificantly. $\mathrm{VO}_{2} \max$ for the investigated $\mathrm{R}$. N. had increased from 56.1 to $67.5 \mathrm{ml} / \mathrm{min} / \mathrm{kg}$, and for A. O. - from 61.2 to $73.4 \mathrm{ml} / \mathrm{min} / \mathrm{kg}$. 
Table 1. Characteristics of kayak rower $R$. $N$. in onwater rowing work in the preparation and competitive mezzo-cycle of February 26-May 16, 2013

Note. R. N. aerobic threshold (AerT) - HR-150 b/pm, anaerobic threshold (ANT) HR-166 b/pm, critical intensity limit, $\mathrm{VO}_{2} \max -\mathrm{HR}-184 \mathrm{~b} / \mathrm{pm}$, $\mathrm{La}-11.9 \mathrm{mmol} / 1$.

\begin{tabular}{|c|c|c|c|c|c|}
\hline Indices & $1^{\text {st }}$ zone & $2^{\text {nd }}$ zone & $3^{\text {rd }}$ zone & $4^{\text {th }}$ zone & $5^{\text {th }}$ zone \\
\hline \multicolumn{6}{|c|}{ Total in $1^{\text {st }}$ mezzo-cycle (February 26-March 17) } \\
\hline Hours & $09: 11: 24$ & 04:00:00 & $02: 46: 25$ & 02:04:11 & $00: 14: 52$ \\
\hline Total $218.7 \mathrm{~km}$ & 101.6 & 49.2 & 35.2 & 28.7 & 4.0 \\
\hline Percentage & 46.5 & 22.5 & 16.1 & 13.1 & 1.8 \\
\hline \multicolumn{6}{|c|}{ Total in $2^{\text {nd }}$ mezzo-cycle (April 22-May 16) } \\
\hline Hours & $05: 31: 11$ & $02: 19: 23$ & $02: 11: 40$ & $01: 56: 57$ & 00:00:00 \\
\hline Total $158.1 \mathrm{~km}$ & 61.5 & 29.0 & 41.4 & 25.5 & 0.7 \\
\hline Percentage & 38.9 & 18.3 & 26.2 & 16.1 & 0.5 \\
\hline \multicolumn{6}{|c|}{ First micro-cycle of $2^{\text {nd }}$ mezzo-cycle } \\
\hline Hours & $01: 16: 14$ & $00: 47: 06$ & $00: 26: 17$ & $00: 15: 51$ & 00:00:00 \\
\hline Total $33.8 \mathrm{~km}$ & 14.6 & 10.0 & 5.8 & 3.4 & 0.00 \\
\hline Percentage & 43.2 & 29.6 & 17.0 & 10.2 & 0 \\
\hline \multicolumn{6}{|c|}{ Second micro-cycle of $2^{\text {nd }}$ mezzo-cycle } \\
\hline Hours & $01: 55: 42$ & $00: 39: 17$ & $00: 50: 03$ & $00: 25: 11$ & $00: 02: 24$ \\
\hline Total $45.2 \mathrm{~km}$ & 21.6 & 8.1 & 10.6 & 4.2 & 0.7 \\
\hline Percentage & 47.7 & 18.0 & 23.5 & 9.2 & 1.6 \\
\hline \multicolumn{6}{|c|}{ Third micro-cycle of $2^{\text {nd }}$ mezzo-cycle } \\
\hline Hours & $01: 43: 03$ & $00: 40: 54$ & $01: 34: 15$ & $01: 00: 45$ & 00:00:00 \\
\hline Total $59.9 \mathrm{~km}$ & 17.8 & 8.0 & 19.9 & 14.2 & 0 \\
\hline Percentage & 29.7 & 13.3 & 33.3 & 23.7 & 0 \\
\hline \multicolumn{6}{|c|}{ Fourth micro-cycle of $2^{\text {nd }}$ mezzo-cycle } \\
\hline Hours & $00: 36: 12$ & $00: 12: 06$ & $00: 21: 05$ & $00: 15: 10$ & 00:00:00 \\
\hline Total $19.2 \mathrm{~km}$ & 7.5 & 2.8 & 5.1 & 3.8 & 0 \\
\hline Percentage & 39.2 & 14.8 & 26.6 & 19.4 & 0 \\
\hline
\end{tabular}

Table 2. Change in kayak rowers' aerobic capacity indices at critical intensity and anaerobic threshold limits during preparatory and competitive mezzo-cycles

\begin{tabular}{|c|c|c|c|c|c|c|c|c|c|c|c|c|c|c|c|c|}
\hline \multirow{2}{*}{ : } & \multirow{2}{*}{$\frac{\frac{\mathscr{U}}{2}}{2}$} & \multicolumn{7}{|c|}{ Critical intensity limit } & \multicolumn{7}{|c|}{ Anaerobic threshold limit } & \multirow{2}{*}{$\begin{array}{c}\mathrm{La}, \\
\mathrm{mmol} / \mathrm{l}\end{array}$} \\
\hline & & $\begin{array}{c}\mathbf{L V}, \\
\mathbf{1} / \mathrm{min}\end{array}$ & $\begin{array}{l}\text { HR, } \\
\text { b/pm }\end{array}$ & $\begin{array}{c}\mathrm{VO}_{2} \max \\
\mathrm{l} / \mathrm{min}\end{array}$ & $\begin{array}{c}\mathrm{VO}_{2} \text { max, } \\
\mathrm{ml} / \mathrm{min} / \\
\mathrm{kg}\end{array}$ & $\begin{array}{c}\text { OP, } \\
\mathrm{ml} / \mathrm{b}\end{array}$ & $\mathbf{W}$ & $\begin{array}{c}\mathrm{O}_{2} \\
1 \mathrm{~W} / \mathrm{ml}\end{array}$ & $\begin{array}{c}\mathrm{LV}, \\
\mathrm{l} / \mathrm{min}\end{array}$ & $\begin{array}{c}\text { HR, } \\
\text { b/pm }\end{array}$ & $\begin{array}{l}\mathrm{VO}_{2} \\
\mathrm{l} / \mathrm{min}\end{array}$ & $\begin{array}{c}\mathrm{VO}_{2}, \\
\mathrm{ml} / \mathrm{min} / \\
\mathrm{kg}\end{array}$ & $\begin{array}{l}\text { OP, } \\
\mathrm{ml} / \mathrm{b}\end{array}$ & $\mathbf{W}$ & $\begin{array}{c}\mathrm{O}_{2}, \\
1 \mathrm{~W} / \mathrm{ml}\end{array}$ & \\
\hline \multirow{2}{*}{ I } & R. N. & 168 & 184 & 4.8 & 56.1 & 26.3 & 280 & 17.3 & 108 & 166 & 3.9 & 45.8 & 23.7 & 210 & 18.6 & 11.9 \\
\hline & A. $\mathrm{O}$. & 156 & 198 & 5.0 & 61.2 & 25.4 & 240 & 20.9 & 116 & 180 & 4.2 & 51.5 & 22.9 & 180 & 23.4 & 7.2 \\
\hline \multirow{2}{*}{ II } & R. N. & 178 & 180 & 5.7 & 67.5 & 31.9 & 320 & 17.9 & 126 & 167 & 4.5 & 52.5 & 26.7 & 240 & 18.6 & 12.2 \\
\hline & A. $\mathrm{O}$. & 135 & 200 & 5.2 & 64.7 & 26.2 & 280 & 18.7 & 94 & 190 & 4.2 & 50.7 & 21.8 & 200 & 20.8 & 12.3 \\
\hline \multirow{2}{*}{ III } & R. N. & 174 & 181 & 5.7 & 66.7 & 31.7 & 320 & 17.9 & 146 & 170 & 5.1 & 58.7 & 29.7 & 260 & 19.4 & 12.6 \\
\hline & A. $\mathrm{O}$. & 147 & 191 & 6.0 & 73.4 & 31.5 & 300 & 20.0 & 106 & 179 & 4.8 & 58.7 & 26.9 & 240 & 20.0 & 8.1 \\
\hline
\end{tabular}


At anaerobic threshold limit, HR indices of the both athletes were rather different. In this zone of intensity, HR for the athlete R. N. was $166-170 \mathrm{~b} / \mathrm{pm}$, and for A. O. - 179-190 b/pm; working capacity of the first athlete had increased from 210 to $260 \mathrm{~W}$, for the second - from 180 to $240 \mathrm{~W}$. Oxygen uptake at anaerobic threshold used to increase significantly from 45.8 to $58.7 \mathrm{ml} / \mathrm{min} / \mathrm{kg}$, for the athlete A. O. from 51.5 to $58.7 \mathrm{ml} / \mathrm{min} / \mathrm{kg}$.

Investigations on aerobic capacity, performed after competitive mezzo-cycle showed different adaptation of the athletes to applied training loads: for the rower R. N. oxygen uptake and working capacity at anaerobic threshold used to increase considerably, and almost no changes were observed for the indices at critical intensity limit, whereas for A. O. considerable increase was established in $\mathrm{VO}_{2}$ max and working capacity indices at CIL. For both athletes, working efficiency at critical intensity and anaerobic threshold was almost constant.

\section{DISCUSSION}

Training load which is being carried out in preparing athletes is divided into different zones of intensity basing on various indices; the majority of the scientists (Платонов, 2004; Wilmore, Costill, Kenney, 2008; Issurin, 2008; Bompa, 2009; Skernevičius et al., 2011) explain such division into zones for the sports with prevailing aerobic capacity due to biochemical processes in muscles. Nevertheless, there are no existing standards for establishment of such zones due to diversity of sports and events, requiring different energy resources; different are physical, physiological and biochemical phenomena of the athletes as well (Astrand, 2001; Karoblis, 2005; Skurvydas, 2009). Our compiled zones of work intensity based on specific athletes' research data may experience slight changes during the training process, altogether with the change in ANT and CIL indices. Our investigation showed decreased amount of rowed kilometres in competitive mezzocycle when workload amount was decreased in the first and the second zones, and it was increased in the third zone (approaching ANT intensity); work in this zone increases blood lactate concentration up to $3.1-5.0 \mathrm{mmol} / 1$. According to В. Н. Платонов (2004), V. Issurin (2008), T. Bompa (2009), the work in this zone improves the function of cardiorespiratory systems without great acidity effect on the body. Intense oxidation processes occur in muscles (Astrand et al., 2003). Workload of our investigated kayak rowers in the fourth zone (when $\mathrm{O}_{2}$ consumption approaches maximal and lactate concentration increases up to $8 \mathrm{mmol} / \mathrm{l}$ ) was of little difference between preparatory and competitive mezzo-cycles. Sport theorists (Hoffman, 2002; Karoblis, 2005; Jeukendrup, Gleeson, 2010; Skernevičius et al., 2011) recommend approaching work intensity to competitive level during practices when preparing for the main competitions in competitive period. Thus, Lithuanian elite kayak rowers, preparing for $1000 \mathrm{~m}$ event in World Championship, should increase workload in the fourth zone and include more work performed in the fifth zone in their preparation program; the work intensity in this zone equals to work at CIL when $\mathrm{O}_{2}$ consumption approaches maximum.

Rowing $1000 \mathrm{~m}$ distance takes from 3 to 4 min; such work causes reaching CIL and $\mathrm{VO}_{2}$ max with great acidity effect on body (Astrand, 2001; Wilmore et al., 2008). To achieve kayak rowers' physical adaptation for such a work, it appears necessary to carry out workload in the fifth zone during training sessions. Analysis of the intensity and volume of our investigated athletes' training sessions in competitive mezzo-cycle shows that very little workload used to be carried out in the fifth zone while preparing for the first competitions of the season (World Cup event).

Investigations on aerobic capacity demonstrated different adaptation of kayak rowers to applied training load: for R. N., aerobic capacity at ANT used to increase considerably, while for A. O. greater increase was established in $\mathrm{VO}_{2}$ max. Such change in the indices highlight different body adaptation trends of the athletes, which should lead to more individualized preparation process regardless the fact that the athletes row one boat.

\section{CONCLUSIONS AND PERSPECTIVES}

1. Elite kayak rowers, preparing for $1000 \mathrm{~m}$ event, carried out less workload in the first and the second zones during the first competitive mezzocycle comparing it to that of preparatory period; the first competitive mezzo-cycle also included an increased workload in the fourth zone, while very little work was performed in the fifth zone. 
2. Preparing for the main competitions of the season, it is purposeful to carry out more work in the fifth zone, as the intensity of the work is close to the competitive.
3. Following the same program, two elite athletes undergo different adaptation to applied training loads. Their preparation is recommended to be more individualized even rowing one boat.

\section{REFERENCES}

Astrand, P.-O. (2001). Aerobic work capacity in men and women with special reference to age. Acta Physiologica Scandinavica, 169, 1-62.

Astrand, P-O., Rodahl, K., Dahl, H., Stromme, S. (2003). Textbook of Work Physiology: Physiological Bases of Exercise. Champaign IL: Human Kinetics.

Balčiūnas, E. (2010). Lietuvos baidarininkų rengimosi 200 m rungčiai ypatumai. Sporto mokslas, 2 (60), 38-45.

Balčiūnas, E. (2009). Lietuvos didelio meistriškumo baidarininku rengimo keturmečiu olimpiniu ciklu ypatumai. Ugdymas. Kūno kultūra. Sportas, 1 (72), 12-19.

Balčiūnas, E., Rudzinskas, M., Skernevičius, J., Pečiukonienè, M., Švedas, E. (2004). Didelio meistriškumo baidarininkų rengimo priešolimpiniu metiniu ciklu analizè. Sporto mokslas, 2 (36), 48-53.

Bompa, T. (2001). Periodizing Training for Peak Performance. High-Performance Sports Conditioning. Modern Training for Ultimate Athletic Development. Champaign, IL: Human Kinetics.

Hoffman, J. (2002). Physiological Aspects of Sport Training and Performance. Champaign, IL: Human Kinetics.

Issurin, V. (2008). Block Periodization. Breakthrough in Sport Training. Ultimate Athlete Concepts. Michigan, USA.

Jeukendrup, A., Gleeson, M. (2010). Sport Nutrition: An Introduction to Energy Production and Performance ( $2^{\text {nd }}$ ed.). Champaign IL.: Human Kinetics.

Kahl, J. (1998). Die Steurung des Ausdauertrainings mit spezifischen Stufentest (feld tests) im Kanurennsport. International Seminar on Kayak-Canoe Coaching and Science. Belgium.

Karoblis, P. (2005). Sportinio rengimo teorija ir didaktika. Vilnius: Inforastas.

Rudzinskas, M., Skernevičius, J., Levinsonienè, A. ir kt. (2001). Baidarininkų rengimo Sidnèjaus olimpinèms žaidynėms kai kurie ypatumai. Sporto mokslas, 1 (23), 22-27.

Rudzinskas, M., Skernevičius, J., Švedas, E., Baškienė, V. (2000). Lietuvos baidarininku rengimo $2000 \mathrm{~m}$. olimpinėms žaidynėms metinio ciklo charakteristika. Sporto mokslas, 1 (19), 37-40.

Rudzinskas, M., Švedas, E., Skernevičius, J., Skernevičienè, B. (1997). Baidarininkų rengimo ypatumai metiniame treniruočiu cikle. Mokslinès konferencijos „,Didelio meistriškumo sportininku rengimo valdymas " medžiaga (pp. 37-41).Vilnius.

Skernevičius, J., Balčiūnas, E., Rudzinskas, M., Švedas, E. (2003). Lietuvos pajègiausių baidarininkų fizinio išsivystymo, fizinio parengtumo ir funkcinio pajėgumo tyrimų duomenys bei jų ryšys su specialiujų galių rodikliais. Sporto mokslas, 1 (31), 66-70.

Skernevičius, J., Dadelienè, R., Balčiūnas, E., Duonèla, A. (2004). Jaunujų baidarininkų specialiojo parengtumo statistiniai duomenys ir jų lyginamoji analizè su pasaulio čempionu rodikliais. Ugdymas. Küno kultūra. Sportas, 3 (53), 50-58.

Skernevičius, J., Milašius, K., Raslanas, A., Dadelienè, R. (2011). Sporto treniruote. Vilnius: VPU.

Skernevičius, J. Raslanas, A., Dadelienè, R. (2004). Sporto tyrimu metodologija. Vilnius: LSIC.

Skernevičius, J., Rudzinskas, M., Švedas, E., Karosiene, J., Skernevičienè, B. (2002). Lietuvos didelio meistriškumo baidarininkų fizinių ir funkcinių galiu kaita pereinamuoju laikotarpiu. Sporto mokslas, 1 (27), 36-39.

Skernevičius, J., Rudzinskas, M., Švedas, E., Skernevičienè, B., Milašius, K. (1998). Baidarininkų fizinio išsivystymo, fizinio darbingumo ir funkcinių galių kitimas per metini treniruočių ciklą. Sporto mokslas, 5 (14), 24-27.

Skurvydas, A. (2009). Judesiu mokslas: raumenys, valdymas, mokymas, reabilitavimas, sveikatinimas, treniravimas, metodologija. Kaunas: LKKA.

Wilmore, J., Costill, D., Kenney, W. (2008). Physiology of Sport and Exercise (4 ed.). Champaign, IL: Human Kinetics.

Платонов, В. Н. (2004). Система подготовки спортсменов в олимпийском спорте. Киев: Олимпийская литература. 


\title{
BAIDARININKŲ, BESIRENGIANČIŲ 1000 M NUOTOLIUI, AEROBINIO UGDYMO YPATUMAI
}

\author{
Ričardas Nekriošius ${ }^{1}$, Rūta Dadelienė ${ }^{2}$, Egidijus Balčiūnas ${ }^{2}$, Kazys Milašius ${ }^{2}$ \\ Lietuvos sporto universitetas ${ }^{1}$, Kaunas, Lietuva \\ Lietuvos edukologijos universitetas ${ }^{2}$, Vilnius, Lietuva
}

\section{SANTRAUKA}

Tyrimo pagrindimas ir hipotezė. Baidarininkams irkluojant $1000 \mathrm{~m}, 81,8 \%$ energijos pagaminama aerobiniu reakcijų būdu. Gerų rezultatų pasiekia tie šio nuotolio sportininkai, kurių santykinis maksimalusis deguonies suvartojimas pasiekia $70 \mathrm{ml} / \mathrm{min} / \mathrm{kg}$.

Lietuvoje spausdinamose mokslo publikacijose daugiau nagrinejjamas baidarininku rengimas 200 ir $500 \mathrm{~m}$ nuotoliams, o Lietuvos baidarininkų rengimasis irkluoti $1000 \mathrm{~m}$ beveik netyrinètas.

Tikslas - suprojektuoti moksliškai pagrįstą baidarininkų rengimą irkluoti 1000 m nuotoli programą, kuri ugdytu aerobini pajègumą atskirais mezociklais ir îvertinti jos veiksmingumą.

Metodai. Tirti dvivietès baidarès igulos nariai, kurie 2013 metų sezono Pasaulio taurès II etapo varžybose iškovojo 5-ą vietą ir pasiekė visų laikų geriausią Lietuvos baidarininkų 1000 m nuotolio rezultatą. Atliktas fizinis krūvis, ugdantis aerobini pajèguma, suskirstytas i penkias intensyvumo zonas. Pratybų metu kompiuterine sistema Garmin Connect buvo fiksuojamas valties i̇veikiamas atstumas, jos greitis, sportininkų pulso dažnis (PD). Dujų analizatoriumi „Oxycon Mobile“ nustatytas sportininkų aerobinis pajėgumas ties kritinio intensyvumo (KIR) ir anaerobinio slenksčio (ASR) riba.

Rezultatai. Baidarininkai tiek parengiamojo, tiek varžybų laikotarpio mezociklais penktoje intensyvumo zonoje dirbo labai mažai. Pažymėtina ir tai, kad važybų laikotarpio mezociklu bendras nuirkluotu kilometru kiekis buvo daug mažesnis. Jis sumažèjo nuo $218,7 \mathrm{~km}$, įveiktų parengiamojo laikotarpio mezociklu, iki 158,1 km.

Aptarimas ir išvados. Didelio meistriškumo baidarininkų, besirengiančių startuoti 1000 m nuotolyje, pirmuoju varžybu mezociklu buvo sumažinta darbo apimtis pirmoje ir antroje zonose, lyginant su parengiamuoju laikotarpiu atlikto darbo apimtimi, ir smarkiai padidintas krūvis ketvirtoje zonoje. Du elitinio meistriškumo sportininkai, treniruodamiesi pagal vieną programą, skirtingai adaptuojasi prie taikomų fizinių krūvių. Rekomenduotina daugiau individualizuoti jų rengimąsi, nors sportininkai startuoja vienoje valtyje.

Raktažodžiai: baidarių irklavimas, parengiamasis ir varžybų laikotarpiai, treniruotès mezociklai, aerobinis pajègumas.

Gauta 20013 m. birželio 17 d.

Received on 17 June, 2013 